\title{
Studi awal perancangan plant pelepasan tinta pada kertas bekas dengan metode flotasi skala laboratorium
}

\author{
Ni Njoman Manik Susantini ${ }^{1 *}$, Nurul Ajeng Susilo ${ }^{1}$ \\ ${ }^{1}$ Program Studi Teknologi Pengolahan Pulp dan Paper, Fakultas Vokasi, Institut Teknologi dan Sains Bandung \\ ${ }^{1}$ Corresponding author: njoman.manik@gmail.com
}

\begin{abstract}
Abstrak. Berkurang ketersediaan bahan baku untuk bahan baku kertas mengakibatkan penggunaan kertas bekas (secondary fiber atau disebut SF) sebagai bahan baku kertas. Hampir semua pabrik pengolahan kertas memilliki unit pelepasan tinta (deinking). Metode deinking yang banyak digunakan adalah Flotasi, yaitu memanfaatkan metode yang memanfaatkan gelembung untuk melepaskan tinta dari SF. Ukuran gelembung yang disarankan di kisaran 0.1-1 mm. Penelitian ini ditujukan untuk mengembangkan metode Flotasi dan untuk hal tersebut diAgar bisa mengembangkan metoda deinking flotation ini maka diperlukan plant deinking dalam skala laboratorium. Alasannya dengan skala dan kapasitas kecil, maka pengembangan metode ini dapat lebih mudah dan murah karena tidak melibatkan industri yang beresiko terganggunya proses produksi. Tantangan lainnya adalah bagaimana membuat kondisi plant semirip mungkin dengan di industri agar jika pengembangan metode sudah berhasil bisa kangsung diaplikasikan. Implementasi dari rancangan ini masih belum memberikan hasil yang menggembirakan, karena diameter gelembung yang dihasilkan masih di kisaran $5 \mathrm{~mm}$. Gerak gelembung juga masih terlalu cepat untuk mencapai permukaan. Tekanan kompresor masih belum bisa bervariasi melainkan hanya di 4 bar saja. Gelembung juga tidak merata di permukaan bak. Oleh karena itu rancangan yang sudah diimplementasikan perlu diperbaiki lagi.
\end{abstract}

Keywords: Secondary Fiber, flotasi, diameter lubang

\section{Pendahuluan}

Kertas bekas sebagai bahan baku pulp atau yang biasa disebut Secondary Fiber (SF) adalah kertas bekas yang diproses ulang untuk kemudian dibuat menjadi produk baru. Di Indonesia, produk yang bisa dibuat dari SF, antara lain kertas coklat (brown paper), kertas seni (art paper) dan kertas karton (paper board). Jika dibandingkan dengan negara lain, misalnya Amerika Serikat dan RRT, lebih banyak jenis kertas yang dihasilkan dari SF yaitu kertas koran, tissue hingga kertas cetak $[1,3]$. Ditinjau dari isu lingkungan, penggunaan SF ini bisa dikatakan sejalan karena mengurangi ketersediaan bahan baku dari hutan. Hal ini berarti ada jumlah yang signifikan dalam pengurangan energi selain pengurangan penebangan hutan. Dengan demikian, saat ini hampir semua pabrik kertas memiliki unit Deinking (pelepasan tinta).

Deinking adalah proses untuk menghilangkan tinta dan obyek non-serat lainnya dari pulp kertas bekas. Tinta pada kertas terutama pada kertas hasil printout komputer memiliki ukuran yang sangat kecil yaitu 12 mikron [2]. Efektifitas proses deinking tergantung beberapa faktor seperti bahan baku kertas bekas, jenis kontaminan terutama tinta, tahapan proses yang dilakukan, dan jenis peralatan yang digunakan. Efektifitas proses deinking ini juga dipengaruhi oleh usia kertas bekas. Penggunaan $100 \%$ kertas koran bekas dengan usia lama memberikan hasil kecerahan (brightness) dan penghilangan bintik yang rendah [3].

Operasi deinking memanfaatkan aksi kimia, mekanis, dan energi panas untuk menghasilkan suspensi berserat dari kertas bekas yang cukup bersih dan cerah untuk digunakan dalam pembuatan kertas dan karton berbagai kelas kualitas tinggi. Untuk mendapatkan hasil yang baik maka ada 3 sub proses yaitu pengelupasan partikel tinta, penempelan partikel tinta pada gelembung dan gelembung yang mengapung di permukaan air dan sudah ditempeli partikel tinta harus dibuang[4]. Sistem deinking biasanya dirancang sesuai dengan kualitas stock (sediaan) hasil yang diinginkan dan jenis yang akan diproses. Teknologi 
mekanik dan kimia yang tersedia pada proses deinking memungkinkan untuk mengolah kertas bekas berkontaminan tinggi.

Proses Deinking ini selain dengan menggunakan mekanik dan kimia, dapat juga menggunakan enzim seperti Selulase-Hemiselulase [5]. Sistem ini termasuk proses biologi. Faktor terpenting adalah mengenal sifat struktur dari enzim. Hal ini dalam proses biologi, mekanisme kerja dari enzim belum sepenuhnya diketahui [4].

\section{Tujuan dan Batasan Pembuatan Plant Deinking Kapasitas Kecil}

Plant Deinking pada industri Pulp dan Kertas memiliki kapasitas yang besar karena jenis kertas yang diproduksi membutuhkan kertas bekas disamping pulp itu sendiri. Besarnya kapasitas ini menjadi kesulitan tersendiri jika akan dilakukan pengembangan terhadap efektifitas metode deinking. Penelitian terkait metode deinking tidak bisa mendapatkan data primer, sebagai syarat penting, untuk validasi hasil. Hal ini karena jika pengujian metode baru dilaksanakan di industri, maka proses produksi akan terganggu.

Dengan melihat kondisi sebagaimana telah disebutkan di atas, maka dirancang plant deinking dengan skala laboratorium. Adanya plant dengan kapasitas kecil ini bisa digunakan untuk pengembangan sistem selain deinking. Misalnya otomasi pengendalian laju aliran untuk deinking, pemantauan kondisi deinking dengan memanfaatkan teknologi komunikasi dll. Walaupun semuanya dengan kapasitas kecil, maka jika sudah ada hasil yang signifikan maka bisa dikembangkan ke kapasitas besar hingga untuk industri.

Agar bisa direalisasikan maka tidak semua parameter pada skala industri dimasukkan dalam perancangan. Parameter yang tetap digunakan adalah ukuran gelembung udara yang digunakan harus sesuai dengan standar. Variabel yang akan dipantau adalah laju aliran udara, tekanan kompresor, konsistensi pulp, jenis kertas bekas yang digunakan dan dosis bahan kimia.

\section{Metode}

\subsection{Flotasi Pada Pelepasan Tinta}

Flotasi adalah cara untuk memisahkan suatu partikel dari partikel lainnya dalam larutan/cairan dengan memanfaatkan perbedaan sifat permukaan dari partikel tersebut. Partikel yang bersifat hidrofilik akan tetap berada di fasa cair sedangkan yang hidrofobik akan melekat pada gelembung udara. Partikel yang melekat pada gelembung akan ikut terbawa ke permukaan cairan dalam bentuk buih. Selanjutnya buih-buih ini kan dapat dipisahkan.

Sebelum proses Flotasi dimulai, pulp di tambahkan bahan kimia surfaktan atau kolektor dan dispersan. Di industri biasanya menggunakan 2 jenis deinking agent yaitu A (DI A) dan B (DI B). Fungsi DI A adalah untuk menarik partikel tinta sehingga terkumpul menjadi partikel yang lebih besar. Sedangkan fungsi DI B adalah menghasilkan busa, sehingga partikel tinta yang sudah terkumpul dapat terapung. Kumpulan partikel tinta yang terapung ini yang akan dibuang sehingga diharapkan didapatkan SF yang sudah bersih.

Komponen utama metoda Flotasi adalah pembuatan gelembung udara yang dihasilkan dari kompresor. Diameter ideal udara yang dihasilkan adalah $0.1-1 \mathrm{~mm}$. Jika diameter lebih kecil dari $0.1 \mathrm{~mm}$ atau lebih besar dari $1 \mathrm{~mm}$ akan menyebabkan proses deinking tidak memberikan hasil yang diharapkan. Dengan demikian langkah awal yang paling penting bagaimana merancang sistem pembentukan gelembung udara dari kompresor sehingga didapat diameter gelembung di kisaran 0.1-1 mm atau rasio diameter gelembung dengan partikel adalah 5:1.

\subsection{Perancangan dan Plant Flotasi}

Proses Deinking terdiri 2 tahap yaitu pembuatan plant dan proses deinking. Pada pembuatan plant, persiapan yang diperlukan selain perancangan sistem juga pemilihan alat pendukung beserta ukurannya seperti kompresor, bak, pipa, katup-katup, flowmeter dan termometer. Jika pembuatan plant ini sudah sesuai standar maka dapat dilanjutkan ke tahap ke 2.

Tahap ke 2 adalah proses deinking itu sendiri yaitu membuat pulp dari SF. Untuk melihat efektifitas dari metode flotasi, maka sampel pulp diambil dari jenis office paper. Alasan pemilihannya karena office paper 
memiliki jenis kontaminan yang tidak terlalu banyak dan tidak banyak partikel tinta terserap di SF. Untuk melihat optimasi SF, maka akan dibuat beberapa varian konsistensi. Langkah akhir dari proses ini adalah pembuatan handsheet untuk kemudian diuji tensile, brightness dan moisture.

Langkah awal pada tahap I adalah melakukan uji pembentukan gelembung dengan kompresor. Tekanan maksimum Kompresor adalah 8 bar. Sebagai bak deinking digunakan bak akrilik berukuran 35.9 x 22x 26.2 $\mathrm{cm}$. Bak jenis ini memiliki rerata volume air yang bisa ditampung adalah 18 liter. Agar tidak terjadi luapan gelembung saat kompresor diaktifkan maka digunakan volume air sebanyak 10 liter. Gelembung udara dibuat dari pipa akrilik yang diberi lubang dengan diameter $5 \mathrm{~mm}$. Pemantauan jumlah aliran udara dari kompresor, dipasang flowmeter. Sementari itu pengatur aliran udara masih menggunakan kran manual, bawaan dari produsen Kompresor.

Skema dari tahap awal pembentukan gelembung deinking adalah sebagai berikut:

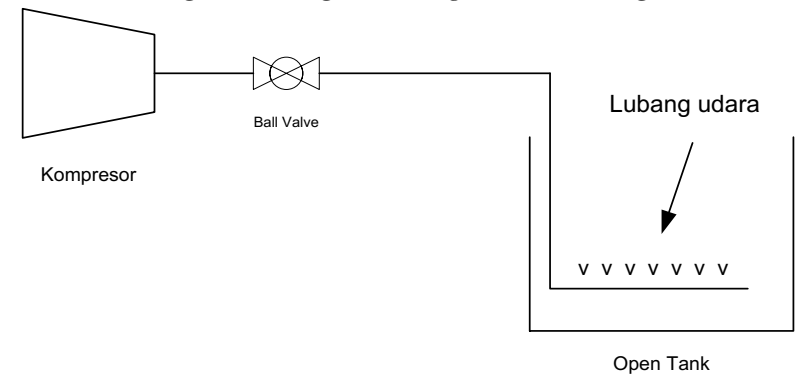

Gambar 7. Skema Plant Deinking

Pipa yang berisi aliran udara dari kompresor diberi lubang dengan jarak antar lubang $1 \mathrm{~cm}$. Tujuan dari lubang ini adalah agar gelembung yang dihasilkan bisa merata. Pipa yang ada di dasar tangki dibuat sedemikian rupa sehingga berbentuk "U" agar semburan udara bisa merata dari dasar tangki ke permukaan. Lubang udara pada pipa dibuat merata dengan diameter $5 \mathrm{~mm}$. Kompresor mencatu udara memiliki tangki penyimpan sebesar 10 liter dan maksimum tekanan 8 bar.

\section{Hasil dan pembahasan}

Percobaan dengan skema awal, seperti yang telah diuraikan di atas, memberikan hasil sebagai berikut:

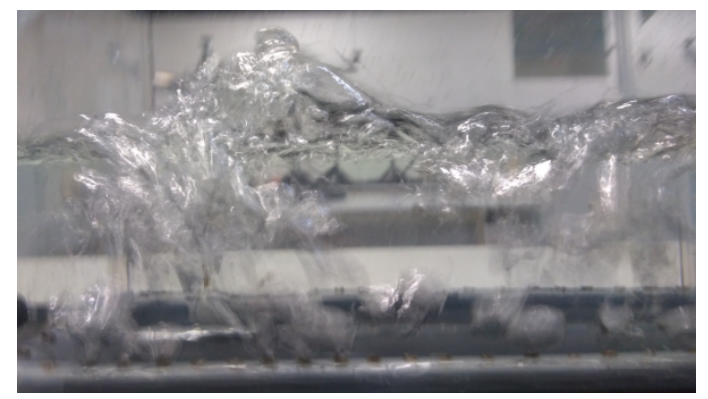

Gambar 8. Gelembung yang terbentuk di tangki percobaan

Pada gambar 2, terlihat gelembung yang muncul belum sesuai dengan yang diharapkan. Semburan udara yang muncul terlalu kencang. Gelembung hanya terbentuk di pipa berhubungan dengan kompresor, sedangkan pada pipa setelah pembelokan, sama sekali tidak terbentuk gelembung. Hal lainnya adalah kompresor hanya bisa digunakan dalam 5 menit.

Dari uraian pada kajian pustaka, diameter gelembung yang bisa melepaskan SF ada di kisaran $0.1 \mathrm{~mm}$ hingga $1 \mathrm{~mm}$. Diameter lubang dibuat sebesar $5 \mathrm{~mm}$ karena saat diameter lubang $<1 \mathrm{~mm}$, tidak terbentuk gelembung. Setelah dilakukan beberapa kali perubahan ukuran dimeter, pada ukuran $5 \mathrm{~mm}$ terbentuk gelembung. Hal ini diduga tekanan dari kompresor tidak cukup untuk meniupkan udara lewat pipa.

Hal lain yang didapat pada uji coba plant adalah ketidakmerataan semburan sepanjang pipa. Secara teoritis, jika pada suatu pipa diberi lubang sepanjang badan pipa, maka daya semburan fluida sepanjang pipa akan makin kecil. Mengacu waktu pengosongan tangki kompresor, dari keadaan penuh, adalah 5 menit (300 
detik), maka diperhitungkan bahwa laju aliran adalah 0,033 liter per detik. Pipa ini diberi lubang sebanyak 20 buah. Dengan asumsi tidak terjadi sumbatan pada semua lubang, maka dari tiap lubang akan keluar sejumlah udara. Makin jauh dari kompresor atau ujung pipa \#1, maka hanya sedikit volume udara yang tersisa. Volume sisa ini akan menumbuk ujung elbow. Setelah tumbukan, fluida akan mengalami pengurangan kecepatan secara signifikan. Dengan demikian tidak ada udara yang bisa disemburkan pada lubang-lubang pipa \#2.

Pada gambar 2 terlihat bahwa gelembung paling banyak terbentuk di lubang yang berada di tengah-tengah pipa. Jika merujuk pada teori bahwa di pangkal pipa memiliki laju aliran paling tinggi, maka gambaran dari uji coba tidak demikian. Penyebab ketidaksesuaian tersebut karena ada lubang yang tidak terbentuk dengan sempurna sehingga saat pembuatan lubang ada serat yang tidak terputus. Kondisi lubang yang seperti inilah yang menyebabkan aliran udara terhalang.

\section{Kesimpulan dan saran}

Plant hasil rancangan awal belum memberikan hasil yang memuaskan. Hal ini terlihat dari diameter gelembung yang dihasilkan lebih besar dari $1 \mathrm{~mm}$. Walaupun dari analisis bahwa jika lubang dibuat $<5 \mathrm{~mm}$ tidak terbentuk gelembung, maka disimpulkan tekanan kurang kuat menyembur dari pipa. Waktu maksimum penggunaan kompresor adalah 30 menit menunjukkan perlunya tangki penyimpan tambahan.

Perbaikan rancangan diarahkan ke ukuran diameter yang bervariasi dari yang berukuran kecil hingga yang besar. Diameter berukuran kecil diposisikan dekat dengan pipa utama sedangkan yang berukuran besar adalah yang paling jauh dari pipa utama. Untuk rancangan pipa sendiri perlu diperbaiki menjadi seperti di bawah ini:

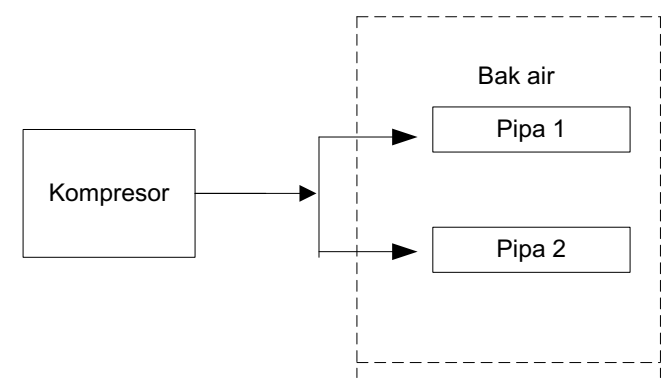

Gambar 9. Skema penyaluran udara dari kompresor

Selain dari ukuran diameter lubang, ukuran bak uji pun harus diperbaiki. Dari dimensi bak, yang paling penting diubah adalah ketinggian bak. Jika tinggi bak terlalu rendah maka hanya sedikit partikel tinta yang tertumbuk gelembung, dan mengurangi efektifitas proses deinking.

\section{Ucapan terima kasih}

Studi awal pembuatan plant deinking ini bisa terlaksana karena bantuan dari berbagai pihak Pada kesempatan ini penulis bersyukur kepada Tuhan YME dan berterima kasih pada:

Yayasan ITSB dengan dukungannya dalam pembiayaan

Mahasiswa program studi Teknologi Pengolahan Pulp dan Kertas ITSB dalam merakit dan uji coba rancangan plant ini

\section{Daftar pustaka}

[1] R. Gong, Disertation, Western Michigan University,( 2013)

[2] Zheng Wei, Thesis, Western Michigan University (2013)

[3] P. Sauve, Thesis, Departement of Chemical Engineering Mc Gill University, Montreal, Quebec, Canada, 1999

[4] R. Svensson, Thesis, Chalmers University of Technology (2011)

[5] J. Rismijana, I.N. Indriani, T. Pitriyani, JMS 8, 67(2003) 